\title{
KAJIAN ESTETIKA MOTIF BATIK GIRILAYU KABUPATEN KARANGANYAR
}

\author{
Sugeng Wardoyo ${ }^{1}$ (Jurusan Kriya, Fakultas Seni Rupa, Institut Seni Indonesia Yogyakarta)
}

\begin{abstract}
Batik craft is a one choice of big part of Girilayu regions, beside to be farmer as theirs main works. The existence of Girilayu batik has influenced from Surakarta batik style, especially influence from Mangkunegaran royal palace, in motifs, technics, and colouring. Surakarta batik style with soft colour, dark blue, dark brown, and yellow white, at the side of Mangkunegaran batik has design style similar with Surakarta batik, but has different in colour i.e. yellow and dark brown dominant. From motif aspect mangkunegaran batik has more creative than Surakarta batik. These motifs are introduced in Girilayu and to be developed and also continues in new era. This research aims in aesthetics mainly in motif which resulted in this area, i.e. relevance with structure and style in art.
\end{abstract}

Keywords: batik aesthetics, Girilayu batik, batik structure, batik style

\begin{abstract}
ABSTRAK
Pekerjaan membatik merupakan pilihan bagi sebagian besar masyarakat Girilayu, di samping bertani sebagai mata pencaharian utama. Keberadaan batik Girilayu mendapat pengaruh dari batik Surakarta, khususnya Keraton Mangkunegaran, baik berupa motif, teknik pembatikan, dan pewarnaan. Motif batik Keraton Surakarta mempunyai ciri khas antara lain dari warna yang cenderung lembut, biru kehitaman, merah kecoklatan, dan krem, sedangkan batik Keraton Mangkunegaran memiliki gaya desain seperti batik Keraton Surakarta pada umumnya, tetapi ciri khas warnanya cenderung warna kuning dan soga yang lebih dominan. Dari segi motifnya batik Mangkunegaran memiliki motif yang lebih kreatif dibandingkan batik Keraton Surakarta karena keragaman dari motif yang dihasilkan. Motif-motif batik inilah yang kemudian diperkenalkan pada masyarakat Girilayu dan dikembangkan serta dilestarikan sesuai dengan perkembangan zaman. Penelitian ini menekankan pada aspek estetika utamanya dari motif yang dihasilkan daerah tersebut, yaitu berkaitan dengan aspek struktur dan gaya.
\end{abstract}

Kata Kunci: estetika batik, batik Girilayu, struktur batik, gaya batik

\section{PENDAHULUAN}

Daerah Girilayu dikenal sejumlah

motif batik klasik dengan gaya Pura
Mangkunegaran. Sentra pembatikan di Desa

Girilayu, Kecamatan Matesih, Kabupaten Karanganyar merupakan salah satu daerah 
pembatikan yang ada sejak masa Mangkunegara I, bersamaan dengan perjanjian Salatiga 17 Maret 1757, dengan ditetapkannya Raden Mas Said menerima sebagian daerah Surakarta, yaitu: Kadawung, Laroh, Matesih, Hariboyo, Honggobayan, Sambuyan, Pajang sisi selatan, Pajang sisi utara, Gunung Kidul, Mataram, dan Kedu (Pringgodigdo, 1938). Daerah-daerah inilah yang kemudian dikembangkan menjadi sentra pembatikan, yang berpusat di Keraton Mangkunegaran.

Desa Girilayu menjadi daerah yang terkenal sebab di sini terdapat kompleks Astana (makam) para penguasa dan kerabat dekat Puro (istana) Mangkunegaran. Selain itu juga di Desa Mangadeg yang masuk Kecamatan Matesih, terdapat makam Mangkunegara I, II, dan III. Sementara di Girilayu terdapat makam Mangkunegara IV, V, VII dan VIII. Karena Girilayu terdapat kompleks makam raja-raja Mangkunegaran, inilah yang kemudian mengangkat penjagapenjaga makam, yang merupakan pembatik keraton, mengembangkan batik di Girilayu dan terus berkembang hingga saat ini.

Pekerjaan membatik merupakan pilihan bagi sebagian besar masyarakat Girilayu, di samping bertani. Dengan demikian, batik Girilayu mendapat pengaruh dari batik Surakarta, khususnya Keraton Mangkunegaran, baik berupa motif, teknik pembatikan, dan pewarnaan. Motif batik keraton Surakarta mempunyai ciri khas antara lain dari warna yang cenderung lembut, biru kehitaman, merah kecoklatan, dan krem, sedangkan batik Keraton Mangkunegaran memiliki gaya desain seperti batik Keraton Surakarta pada umumnya, tetapi ciri khas warnanya cenderung warna kuning dan soga yang lebih dominan. Dari segi motifnya batik Mangkunegaran memiliki motif yang lebih kreatif dibandingkan batik Keraton Surakarta karena keragaman dari motif yang dihasilkan
(Doellah, 2001:56). Motif-motif batik inilah yang kemudian diperkenalkan pada masyarakat Girilayu dan dikembangkan serta dilestarikan sesuai dengan perkembangan zaman.

Berkaitan dengan uraian dan penjelasan tersebut di atas, dalam artikel ini akan dikaji secara fokus motif batik khas Girilayu Kabupaten Karanganyar. Penerapan motif dan spesifikasi unsur warna yang diterapkan pada batik akan menjadi bahan kajian utama yang akan dititikberatkan pada aspek analisis estetika. Hal ini dilandasi oleh fakta sejarah, bahwa produk budaya batik ini memiliki latar belakang yang sarat dengan muatan budaya dan tradisi yang berakar dari warisan kerajaan Mataram di pulau Jawa, dengan berbagai faktor yang memengaruhi dan kepercayaan yang melatarbelakanginya.

\section{PEMBAHASAN}

Secara spesifik, struktur ragam hias pada batik merupakan struktur atau prinsip dasar di dalam penyusunan sebuah visualisasi batik secara keseluruhan. Seperti penjelasan sebelumnya bahwa struktur batik klasik terdiri atas unsur pola atau ragam hias batik yang disusun berdasarkan pola yang baku. Terdapat tiga elemen penyusun struktur batik klasik, yaitu: (1) ragam hias utama, sebagai unsur pokok pola berupa gambar-gambar bentuk tertentu, dikarenakan menjadi unsur pokok maka ia disebut ornamen pokok atau utama; (2) ragam hias pengisi, sebagai pola berupa gambar-gambar yang dibuat untuk mengisi bidang, dengan bentuknya yang lebih kecil dan tidak ikut membentuk arti atau jiwa dari pola tersebut, sehingga disebut ornamen pengisi atau selingan; dan (3) isèn-isèn, sebagai elemen untuk memperindah pola secara keseluruhan, baik itu ornamen pokok maupun ornamen pengisi yang diberi isian hiasan berupa cecek atau titik, sawut atau garis, dan gabungan antara cecek atau titik 
dan sawut atau garis tersebut. Lazimnya, isènisèn pada batik klasik memiliki bentuk dan nama tertentu dengan jumlah yang banyak. Struktur batik akhirnya menjadi paduan ragam hias maupun pola yang terdiri atas ragam hias utama. Di samping ragam hias selingan yang secara variatif menghiasi keseluruhan merupakan elemen rupa atau idiom dan sekaligus memperkuat keseimbangan komposisi atau tata-susun dalam struktur batik. Dengan demikian, secara keseluruhan dapat memberikan satu kesatuan atau unity pola susunan batik. Sementara itu, ragam hias isian atau isèn-isèn terdiri atas cecek atau titik yang dipadukan dengan unsur sawut atau garis yang diterapkan pada bagian ragam hias pokok maupun pada selingan yang merupakan variasi guna memberikan rasa estetis atau keindahan pada batik secara keseluruhan (Dharsono, 2007: 87). Struktur atau tata susun pada batik, selanjutnya disebut komposisi dari unsur-unsur yang lazim disebut sebagai pola. Pola itu sendiri terdiri atas sejumlah ragam hias. Dengan demikian, tata susun batik adalah susunan dari adanya pengulangan pola batik sebagai sebuah susunan dari ragam hias (Dharsono, 2007: 179).

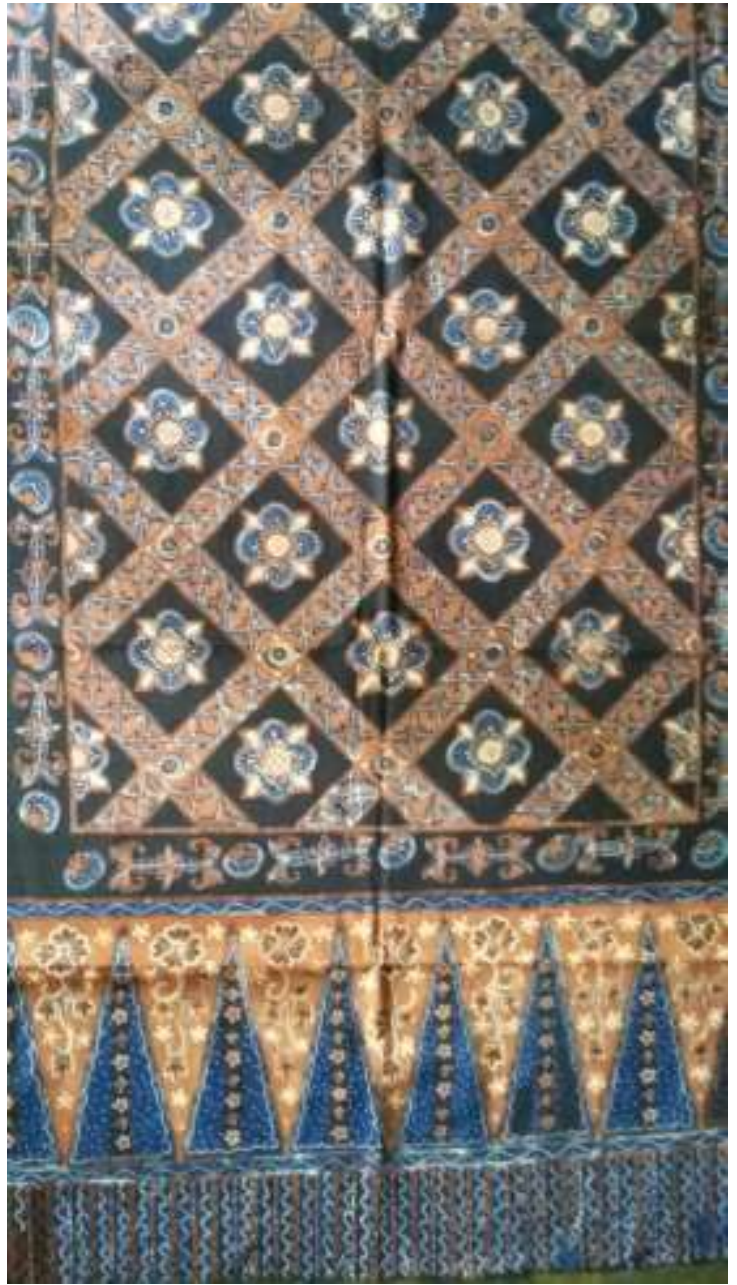

Gambar 1. Motif Manggisan 1

Motif manggisan diambil dari nama buah Manggis. Motif ini termasuk dalam susunan batik motif Ceplok khas pedalaman dengan motif tumpal khas pesisiran. Motif Manggis sebagai unsur ragam hias utama disusun dalam formasi tengah di antara ceplok digambarkan dalam bentuk dasar lingkaran. Pada tiap-tiap petak juga diisi dengan motif Ceplok dalam ukuran kecil. Unsur isian yang diterapkan tampak adanya cecek dan sawut. Unsur warna pedalaman masih cukup nampak diterapkan meskipun juga dikombinasikan dengan warna pesisiran. Ciri khas dari batik pesisiran tampak pada penerapan tumpal. Dapat dikatakan motif Manggisan merupakan perpaduan antara batik pedalaman dan pesisiran. Pada tumpal terdapat unsur ukel, sulur, daun, dan bunga. 
Terdapat motif Ceplok pada pinggiran yang menegaskan adanya pengembangan motif dasar yang diambilkan dari unsur buah Manggis.

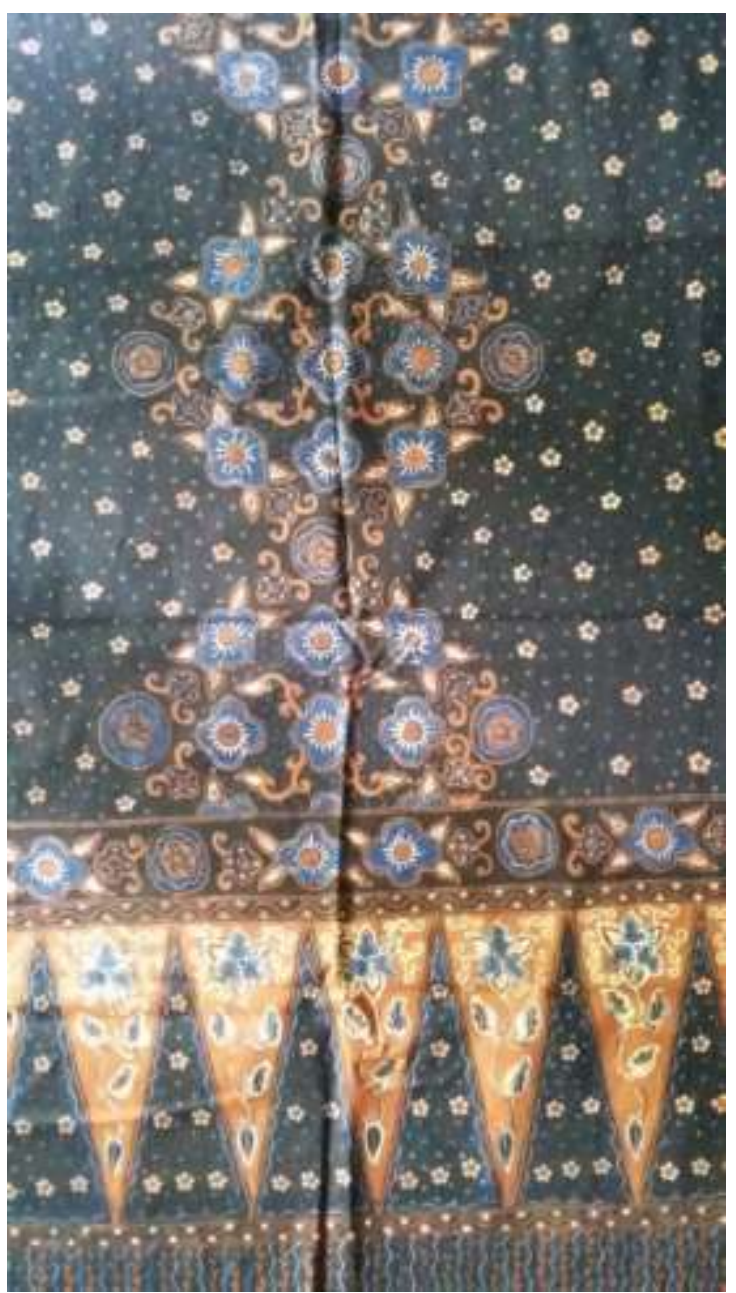

Gambar 2. Motif Manggisan 2

Motif batik kedua masih mengambil tema Manggisan. Manggisan diambil dari nama buah Manggis. Motif 2 ini termasuk dalam susunan batik motif Ceplok khas pedalaman dengan motif tumpal khas pesisiran. Sudah ada pengembangan struktur motif manggisan pada motif 2 ini jika dibandingkan dengan motif 1 . Motif Manggis yang disusun dalam formasi tengah di antara ceplok digambarkan dalam bentuk dasar lingkaran. Variasi pada motif 2 ini dikombinasikan dengan motif Truntum sebagai salah satu ciri khas batik pedalaman.
Bidang-bidang berupa petak-petak dalam formasi vertikal dan belah ketupat diisi dengan motif Ceplok sebanyak sembilan buah dalam ukuran agak besar. Unsur warna pedalaman masih cukup tampak diterapkan meskipun juga dikombinasikan dengan warna pesisiran. Ciri khas dari batik pesisiran tampak pada penerapan tumpal. Dapat dikatakan motif 2 ini juga merupakan perpaduan antara batik pedalaman dan pesisiran. Pada tumpal terdapat unsur ukel, sulur, daun, dan bunga. Terdapat motif Ceplok, pinggiran yang menegaskan adanya pengembangan motif dasar yang diambilkan dari unsur buah Manggis. Unsur isian berupa sejumlah cecek atau titik dan garis atau sawut.

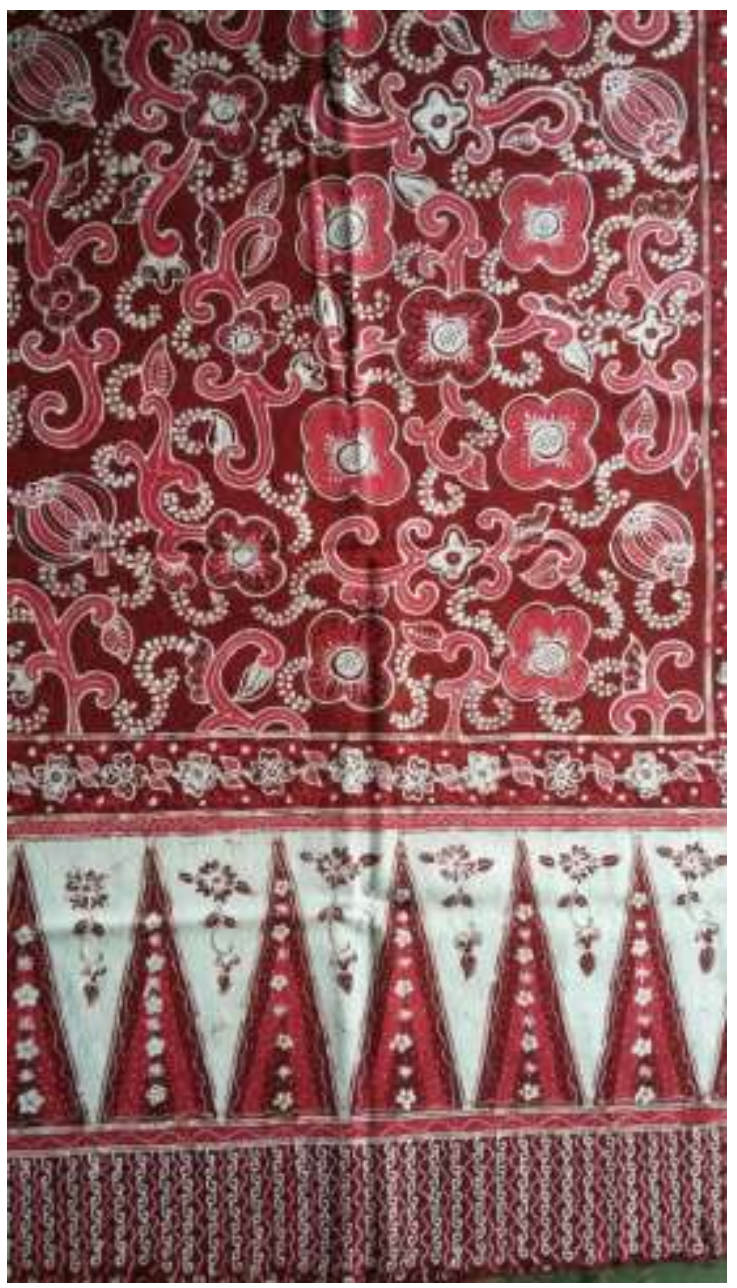

Gambar 3. Motif Manggisan 3 
Motif batik ketiga masih mengambil tema Manggisan. Manggisan diambil dari nama buah Manggis. Motif 3 ini termasuk dalam susunan batik motif nongeometris sebagai salah satu ciri khas pedalaman dengan motif tumpal khas pesisiran. Sudah ada pengembangan struktur pohon dan buah motif Manggis pada motif 3 ini. Buah Manggis yang disusun dalam formasi secara lebih bebas dan acak digambarkan dalam bentuk dasar lingkaran. Variasi pada motif 3 ini dikombinasikan dengan motif Truntum sebagai salah satu ciri khas batik pedalaman. Bidang-bidang berupa petak-petak dalam formasi vertikal dan belah ketupat diisi dengan motif Ceplok sebanyak sembilan buah dalam ukuran agak besar.

Unsur warna dengan gaya warna pesisiran yang menonjolkan warna merah. Ciri khas dari batik pesisiran tampak pada penerapan tumpal. Dapat dikatakan motif 3 ini juga merupakan perpaduan antara batik pedalaman dan pesisiran. Pada tumpal terdapat unsur ukel, sulur, daun, dan bunga. Terdapat motif Ceplok, pinggiran yang menegaskan adanya pengembangan motif dasar yang diambilkan dari unsur buah, bunga, daun, dan buah manggis.

Motif batik 4 masih mengambil tema Manggisan. Manggisan diambil dari nama buah Manggis. Motif 4 ini termasuk dalam susunan batik motif nongeometris khas pedalaman. Motif manggis yang disusun dalam formasi nongeometris ini divariasikan dengan format batik pesisiran yang memiliki unsur tumpal dan hiasan pada bagian tepi. Unsur warna pedalaman yaitu hitam masih cukup tampak diterapkan meskipun juga dikombinasikan dengan warna pesisiran. Ciri khas dari batik pesisiran tampak pada penerapan tumpal. Dapat dikatakan batik ini merupakan perpaduan antara batik pedalaman dan pesisiran yang menampilkan unsur warna biru muda. Pada tumpal terdapat unsur ukel, sulur, daun, dan bunga. Terdapat motif Ceplok, pinggiran yang menegaskan adanya pengembangan motif dasar yang diambilkan dari unsur buah Manggis.

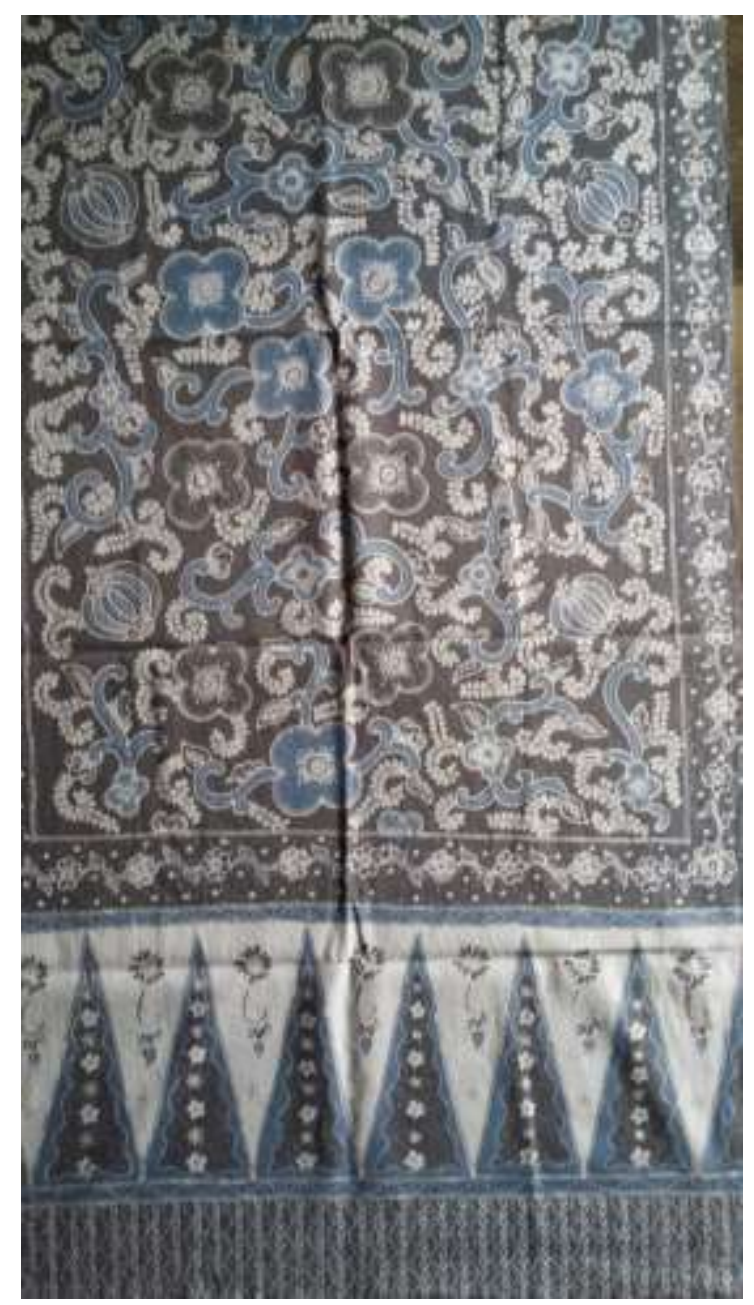

Gambar 4. Motif Manggisan 4 


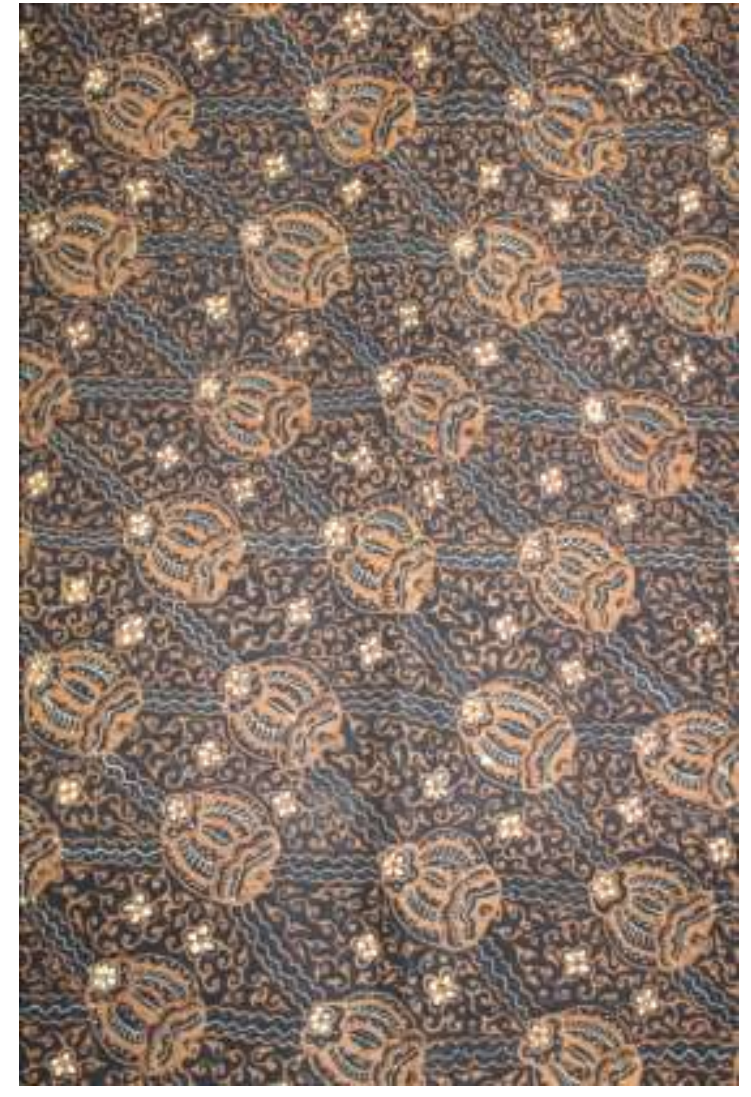

Gambar 5. Motif Manggisan 5

Motif 5 masih mengambil tema Manggisan. Manggisan diambil dari nama buah Manggis. Motif 5 ini termasuk dalam susunan batik motif Ceplok khas pedalaman yang disusun dalam formasi diagonal. Sudah ada pengembangan struktur motif Manggisan pada motif 5 ini jika dibandingkan dengan motif sebelumnya. Motif Manggis yang disusun dalam formasi ceplok digambarkan dalam bentuk dasar setengah lingkaran dan saling bersambungan antara unsur motif yang satu dengan unsur motif lain secara repetitif. Variasi pada motif 5 ini dikombinasikan dengan ukel atau sulur sebagai salah satu ciri khas batik pedalaman. Bidang-bidang berupa petak-petak dalam formasi vertikal dan belah ketupat diisi dengan motif Ceplok sebanyak sembilan buah dalam ukuran agak besar. Unsur warna pedalaman sangat tampak dengan diterapkannya unsur warna soga dan krem. Dapat dikatakan motif 5 ini merupakan representasi ciri khas dari batik pedalaman.
Berbicara aspek gaya pada ragam hias batik Girilayu, maka analisis awal dapat ditelusuri dan dicermati dari hadirnya budaya membatik di wilayah ini. Pengaruh batik pedalaman cukup kuat dalam perkembangan dan kesinambungan seni batik di Girilayu selanjutnya. Proses terbentuknya gaya batik khususnya di Girilayu juga tidak terlepas dari adanya suatu pola hubungan sosial budaya, utamanya dari lingkungan keraton yang akhirnya menempatkan raja pada kedudukan yang paling tinggi, yaitu keberadaannya diyakini sebagai wakil Tuhan di dunia. Masuknya batik di wilayah keraton selanjutnya menjadi manifestasi pengabdian kepada raja. Dikarenakan memasuki lingkungan keraton, teknik, ragam hias, dan warna yang diterapkan secara otomatis juga semakin diperhalus lagi. Guna mendukung hal tersebut maka diciptakanlah sejumlah ragam hias yang bermutu tinggi, sehingga layak dipersembahkan kepada raja dan kerabatnya. Dengan demikian, kecenderungan arah gaya batik di Girilayu tentu tidak dapat terlepas begitu saja dari adanya pengaruh pusat kekuasaan yang terfokus dalam diri seorang raja. Kedudukan wali sebagai pemuka agama yang seringkali juga sekaligus sebagai empu, kemudian menjadi panutan dan tuntunan bagi para raja yang memerintah kerajaan Islam selanjutnya. Seringkali pula disebutkan bahwa dalam sejarah para raja yang di samping kedudukannya sebagai pemimpin tertinggi dalam pemerintahan, juga dikenal sebagai seorang empu. Pola kegiatan berkesenian yang ditunjang dan secara langsung dipimpin oleh para raja inilah yang kemudian mampu mendorong timbulnya suasana seni yang berhasil menjamin kelestarian akan tradisi kebudayaan istana secara turun-temurun dan berkesinambungan (Yudoseputro, 1986: 6).

Pembinaan kesenian yang bersumber dan dilakukan dari dalam istana ini pada akhirnya mampu menghasilkan pedoman dan 
kaidah seni hasil dari pengalaman, pendalaman, dan peningkatan daya cipta para seniman istana. Puncak-puncak prestasi dari para empu, selanjutnya mampu mencerminkan adanya kesempurnaan mutu seni yang kemudian dihadirkan sebagai contoh dan panduan klasik dalam kegiatan berkesenian selanjutnya. Gaya klasik seni istana ini pada akhirnya turut memiliki andil sekaligus mampu memberikan warna tersendiri bagi perkembangan dan pembentukan seni Islam di Indonesia pada umumnya. Pada masa kebudayaan Islam terdapat sebuah perpaduan yang selaras dan harmonis antara rasa dan pikiran. Dengan demikian, hasil yang telah dicapai pada zaman Hindu baik itu secara teknis maupun estetis pada zaman Islam mampu dikembangkan, diperbaharui, dan disempurnakan lagi dengan ditampilkannya unsur-unsur yang baru (Yudoseputro, 1986: 97).

Adanya jalinan hubungan antara kebudayaan istana dengan kebudayaan masyarakat agraris atau petani, pada akhirnya mengakibatkan adanya pola penyebaran tradisi seni feodal yang keluar dari lingkungan istana. Para cantrik dengan pengalaman seni yang telah dimilikinya, turut pula berperan serta secara aktif dalam proses pertumbuhan dan perkembangan seni dalam masyarakat dengan skala yang lebih luas, namun tetap mempertahankan nilai tradisi seni feodal. Hal yang demikian itu kemudian mampu memunculkan tenaga-tenaga perajin dengan karya kerajinan bergaya seni feodal yang bekerja untuk para pengusaha dan pemimpin adat dalam masyarakat. Oleh karena itu, yang terjadi selanjutnya adalah adanya pola berlakunya proses penularan kecakapan seni yang membutuhkan kehadiran tradisi kesenian baru dalam masyarakat pendukungnya tersebut (Yudoseputro, 1986: 6-8).
Gaya dalam seni batik selanjutnya dapat pula dipahami sebagai sebuah ciri yang dimiliki suatu daerah penghasil batik. Gaya akhirnya dapat menjadi representasi dari sesuatu atau sebagian unsur-unsur tertentu yang dapat membedakan antara satu daerah dengan daerah lainnya. Masuknya pengaruh agama Islam sebagai penuntun hidup yang baru di Jawa, sedikit banyak juga mengakibatkan adanya perubahan sosial yang terjadi. Orientasi agama Islam yang lebih demokratis memiliki andil dan turut memengaruhi daya kreativitas penciptaan seni batik, termasuk di dalamnya adalah aspek pengembangan dari unsur ragam hiasnya (Riyanto, 1997: 9). Apabila diperhatikan, pengembangan ragam hias batik klasik pada zaman Islam selalu terdapat beberapa gaya dan unsur dari ragam hias pada masa sebelumnya, seperti halnya yang termuat pada ragam hias batik klasik Girilayu.

Kajian tentang gaya dalam sebuah karya seni rupa seperti batik adalah segala sesuatu yang juga memiliki relevansi secara mendasar dengan aspek telaah visual berwujud garis, elemen bentuk atau dalam hal ini adalah ragam hias, warna, dan tekstur (Feldman, 1967: 132-136). Dengan demikian di dalam memahami gaya dari ragam hias batik klasik Girilayu, dapat diuraikan pula dari bahan yang dipergunakan sebagai media, teknik yang diterapkan, ekspresi garis yang dihasilkan, bentuk dari elemen ragam hias dan isian yang diterapkan, serta warna yang dimunculkan.

Penggambaran makhluk hidup yang banyak dihindari karena berkaitan dengan adanya larangan dalam ajaran agama Islam mendapatkan jalan yang cerdas dalam ungkapan ragam hias batik, yaitu tetap diakomodasi dengan cara menyamarkan sosoknya yang memang gejala tersebut sudah ada di masa sebelumnya. Stilisasi pada dasarnya merupakan salah satu cara 
penggayaan terhadap ragam hias makhluk bernyawa, seperti binatang. Melalui cara distilisasi yang sangat jauh, mengakibatkan adanya sebuah gubahan abstraksi bentuk. Gubahan abstraksi bentuk melalui stilisasi ini dapat dilakukan dengan cara mempertahankan proporsi bentuk ragam hiasnya maupun dengan jalan mengubah proporsinya. Di samping stilisasi, muncul pula gejala penyamaran bentuk dan ornamen hasil perpaduan atau transformasi antara binatang dengan tumbuhan, sebagai sesuatu hal yang lazim dilakukan. Dalam ragam hias baru ini, unsur ragam hias binatang selanjutnya digayakan sebagai sebuah perwujudan ragam hias tumbuhan. Penggayaan ini dilakukan sedemikian rupa, sehingga seringkali untuk mengidentifikasikannya perlu dilakukan pengamatan secara jeli dan teliti (Amin, 2002: 33).

Ragam hias tumbuhan menjadi salah satu tema sentral yang semakin subur dan mendapat tempat yang istimewa. Sebaliknya pada unsur ragam hias manusia, binatang, atau ragam hias makhluk hidup lainnya yang dikenal pada masa Hindu, cenderung menjadi semakin surut. Kendati demikian, tidak selamanya ragam hias yang diambil dari unsur flora tersebut mengandung makna simbolis. Hal ini dikarenakan gubahan-gubahan yang kemudian dilakukan pada unsur ragam hias tumbuhan, seringkali menjadi lebih ditekankan pada segi keindahan hiasan secara visual semata. Terutama jika jenis tanaman yang diterapkan sebagai ragam hias itu tidak dapat diidentifikasi secara jelas. Dengan kata lain, secara spesifik tampilannya tidak menggambarkan suatu jenis tumbuhan maupun unsur tumbuhan tertentu.

Seiring berkembangnya seni batik yang meluas ke berbagai wilayah khususnya di Jawa, terdapat sejumlah pengembangan ragam hias binatang sesuai dengan ciri khas daerah setempat. Akan tetapi yang paling dikenal dan menonjol adalah ragam hiasragam hias batik klasik yang berasal dari daerah pedalaman, seperti Surakarta dan Yogyakarta, serta ragam hias batik dari daerah pesisiran. Ragam hias binatang pada ragam hias batik pesisiran umumnya digambarkan secara lebih realistis jika dibandingkan dengan ragam hias binatang pada batik pedalaman, seperti di Surakarta dan Yogyakarta yang telah mengalami proses stilisasi (Sunaryo, 2009: 66). Berdasarkan penjelasan ini, unsur ornamen yang paling banyak diterapkan ke dalam ragam hias batik klasik pedalaman seperti pada ragam hias Semèn, di samping diambilkan dari unsur tumbuhan juga diambil dari unsur binatang terutama adalah burung (Sunaryo, 2009: 12).

Selain dari itu terbentuknya gaya batik klasik pedalaman seperti di Girilayu, sesungguhnya juga turut diilhami oleh suasana batin dan kejiwaan masyarakat Jawa dalam kurun waktu tertentu. Hal ini juga turut dipengaruhi oleh adanya anggapan bahwa datangnya sumber kekuasaan itu berasal dari kekuatan-kekuatan magis yang dihubungkan dengan sumber kekuatan alam, misalnya awan di langit, bintang di malam hari, matahari bersinar terang, rembulan bercahaya redup, laut selatan bergelombang dahsyat, gunung berapi memuntahkan lahar panas, pusaka-pusaka keramat pembawa kesaktian, kereta kencana yang penuh misteri, kuda-kuda, dan persenjataan perang. Materimateri inilah yang kemudian juga turut diolah guna menciptakan sejumlah elemen ragam hias baru yang akhirnya juga tampak diterapkan pada motif batik Girilayu.

Terjadinya proses interaksi dan akulturasi dari berbagai elemen luar seperti penjelasan di atas, pada akhirnya turut memengaruhi dan mewarnai arah gaya batik Girilayu kepada titik dasar yang lebih menekankan pada kekuatan daya cipta seni semata. Dari perspektif visual, salah satu ciri 
yang dimiliki oleh batik klasik pedalaman pada umumnya memiliki tampilan yang padat, seolah tidak memberikan ruang kosong pada lembar desainnya, yang ditempati oleh adanya penerapan isèn-isèn pada tiap bidang yang terluang. Hal tersebut dapat diibaratkan sebagai sebuah cerminan begitu kuatnya ikatan kehidupan sosial masyarakat Jawa dalam satu wadah sosio-kultur yang padu. Pengagungan terhadap pusat kekuasaan seorang raja pada akhirnya kemudian dapat diartikan sebagai sumber kekuatan magis (Dofa, 1996: 31-33).

Di samping adanya beberapa faktor pembentuk gaya seni batik di Girilayu seperti uraian di atas, di dalamnya juga termasuk adanya konsep dasar-dasar simbolisme yang cukup kuat dalam kehidupan masyarakat Jawa itu sendiri. Adanya muatan makna simbolis yang dikenal sebagai salah satu penciri gaya batik klasik seperti ini, asal-muasalnya adalah berasal dari berbagai kepercayaan pada masa lampau. Semenjak zaman prasejarah hingga kini, masyarakat Jawa telah mengalami berbagai macam kepercayaan dan agama, mulai dari animisme-dinamisme, Hindu, Buddha, dan Islam. Setelah datangnya agama seperti Hindu dan Buddha di Jawa, kepercayaan terhadap animisme-dinamisme tidak lantas menjadi hilang. Begitu pula setelah disusul dengan kehadiran agama Islam, maka kepercayaan terhadap mitologi Hindu dan inkarnasi pada kenyataannya juga tidak lenyap begitu saja. Unsur-unsur pandangan hidup yang relevan dengan animisme-dinamisme, Hindu, dan Buddha tersebut, hingga kini masih terpatri dan melekat di dalam hati masyarakat Jawa yang mayoritas penduduknya adalah pemeluk agama Islam (Suyanto, 2000: 24-25).

Berdasarkan pemahaman tersebut di atas, penerapan sejumlah unsur ragam hias yang kemudian disebut sebagai pola klasik seperti yang telah dijelaskan sebelumnya, adalah yang kental dengan muatan makna simbolisnya, sebagai salah satu ciri-utamanya. Hal ini sangat relevan dengan pandangan dan pola kehidupan masyarakat Jawa yang banyak dipengaruhi oleh perilaku simbolis. Pola perilaku seperti ini sejatinya juga telah dipergunakan semenjak lama baik oleh individu, golongan penguasa, suku bangsa, maupun oleh bangsa di muka bumi ini melalui berbagai macam cara dan media (Affandi, 1999: 2).

\section{PENUTUP}

Keberadaan seni batik tulis di desa Girilayu tidak terlepas dari adanya pengaruh batik pedalaman karena berada di wilayah Surakarta. Faktor alam lingkungan mendukung dengan berlimpahnya buah Manggis yang kemudian menghasilkan motif Manggisan sebagai tema utama. Dari aspek alat, bahan, dan teknik banyak mengacu pada batik pedalaman yaitu teknik lorodan sebagai teknik yang paling banyak diterapkan.

Struktur motif batik Girilayu merupakan perpaduan antara batik pedalaman dan pesisiran. Hal ini tampak dari adanya struktur motif Ceplok dan juga adanya struktur motif yang menjadi ciri khas batik pesisiran, yaitu diterapkannya ceplok dan hiasan pinggir. Warna juga demikian, sangat tampak ciri khas warna batik pedalaman, yaitu biru tua dan coklat sebagai ciri khas batik pedalaman. Perkembangan selanjutnya adalah juga diterapkannya warna batik pesisiran yang didukung oleh penggunaan zat warna sintetis.

\section{DAFTAR PUSTAKA}

Dharsono, Sony Kartika. 2004. Pengantar Estetika. Bandung: Rekayasa Sain. 2007. Budaya Nusantara: Kajian Konsep Mandala dan Konsep Triloka/Buana terhadap Pohon Hayat 
pada Batik Klasik. Bandung: Rekayasa Sains.

Djoemena, Nian S. 1990. Batik dan Mitra: Batik and Its Kind. Jakarta: Djambatan.

Doellah, H. Santoso. 2002. Batik: The Impact of Time and Environment. Solo: Danar Hadi.

Feldman, Edmund Burke. 1967. Art as Image and Idea. New Jersey: Prentice Hall, Inc., Englewood Clift.

Susanto, S.K., Sewan. 1980. Seni Kerajinan Batik Indonesia. Yogyakarta: Balai Penelitian Batik dan Kerajinan, Lembaga Penelitian dan Pendidikan Industri Departemen Perindustrian RI.

Suyanto, A.N. 2002. "Makna Simbolis Motifmotif Batik Busana Pengantin Jawa." Laporan penelitian tidak diterbitkan, Lembaga Penelitian Institut Seni Indonesia Yogyakarta.

2002. Sejarah Batik Yogyakarta. Yogyakarta: Rumah Penerbitan Merapi. 